\title{
ACUTE IDIOPATHIC HAEMOLYTIC ANAEMIA
}

\author{
BY \\ J. G. MILLICHAP \\ From The Hospital for Sick Children, Great Ormond Street, and the Children's Department, St. Bartholomew's \\ Hospital, London
}

(RECEIVED FOR PUBLCATION SEPTEMBER 10, 1951)

Referring to the disease as new and hitherto unreported, in 1925 Lederer recorded three cases of acute haemolytic anaemia of probably infectious origin. In 1930 he described three additional cases of sudden onset with elevation of temperature, leucocytosis and severe anaemia resembling pernicious anaemia, all of which symptoms promptly and rapidly disappeared following a single transfusion. No mention was made of isohaemolysins or auto-agglutinins in the sera of these patients, the previous work of Chauffard, Troisier and Vincent (1908) and of Widal, Abrami and Brulé (1907) having, apparently, been overlooked.

In view of these earlier descriptions, it seems that the eponym 'Lederer's anaemia' is unwarranted, and that this disease, which responds dramatically to a single transfusion, merely represents one form of acute idiopathic haemolytic anaemia.

\section{Diagnostic Criteria}

The features of the disease as defined by Lederer may be expanded: (1) the onset may be acute and fulminating with haemoglobinuria, or subacute, with a history of one to three months of gradually increasing fatigue and weakness accompanied by anaemia and fever (Dameshek and Schwartz, 1940); (2) examination of the blood may show spherocytosis and increased red cell fragility; (3) auto-agglutinins, sometimes present in the serum, may cause difficulty in blood grouping; (4) transfused normal cells are eliminated from the circulation at an accelerated rate (Loutit and Mollison, 1946); (5) recovery, at times spontaneous, may follow transfusions, either single or multiple; (6) response to splenectomy is variable; (7) the history and examination disclose no obvious cause such as bacteria, chemicals, drugs and neoplasms for the haemolytic process; (8) the previous health and family history is devoid of any similar illness.

With intravenous transfusions alone four of the following five patients recovered, while one in whom haemolysis continued died despite splenectomy.
Case Reports

Case 1. Marilyn B., aged 18 months, was admitted to The Hospital for Sick Children, Great Ormond Street, on January 4, 1951, under the care of Dr. W. G. Wyllie. There was a history of loss of appetite for 14 days and fever, with cold, cough and conjunctivitis for 10 days. Two days before admission the cough became more severe, there was a shivering attack and the child vomited once. The following day a second shivering attack occurred accompanied by vomiting, and port wine-coloured urine was passed. Jaundice and pallor were noticed on the day of admission. There was no abdominal pain; the bowels were opened daily. A history of contact with substances known to cause haemolytic anaemia was not obtained.

The patient was an only child. Her father gave a history suggestive of a recent attack of virus pneumonia. Her mother had suffered from a cold 12 days previously. On admission the child was drowsy, very pale, and moderately jaundiced. There was no pyrexia. A purulent nasal discharge was noted and the right tympanic membrane was pink. A systolic murmur was audible at the apex of the heart. No abnormal signs were elicited on examination of the lungs. The liver was palpable half an inch below the costal margin; the spleen was not felt. The napkin was pink.

A spectroscopical examination of the urine performed by Dr. W. W. Payne revealed the presence of methaemoglobin and methaemalbumin. The blood plasma contained methaemalbumin.

The haematological findings were as follows: B.S.R. $90 \mathrm{~mm}$; blood urea, $74 \mathrm{mg} . \%$; Hb. 36\% (Sahli) (5.1 g.\%); R.B.C., 1.47 m. per c.mm.; leucocytes, 19,100 (P. $81 \%$, L. 19\%); The platelets were agglutinated and uncountable one day after admission; there were 190,720 per c.mm. four days later. Reticulocytes, 4.6\%. Anisocytosis, anisochromia and apparent spherocytosis of red cells were reported. No malarial parasites were seen. The direct Coombs, Mourant and Race test was positive on the second, fifth, eighth, 13th, 15th, 19th and 25th days after admission. The blood group of the patient was AII R, mother, OIV R, and father, AII $R$. Red cell fragility five days after admission: haemolysis began at $0.51 \%$ saline concentration and was complete at $0.33 \% ; 13$ days after admission, haemolysis began at $0.45 \%$ and was complete at $0.36 \%$. The serum Wassermann reaction of the patient and both parents was negative.

The chest radiograph was clear six days after admission. 
The father's serum contained no cold agglutinins and a radiograph of his chest was clear. The latter was performed 24 days after the onset, and seven days after recovery from his respiratory illness.

For the following report on this patient's serum and also that of Case 2, I am indebted to Dr. I. A. B. Cathie:

'Owing to auto-agglutination there was some difficulty in determining the patient's blood group, which was eventually established as AII $R$. The patient's serum contained an antibody which agglutinated the cells of seven AII $R$ donors and nine group OIV $R$ donors. The patient's own cells were also agglutinated. Agglutination was seen only when the cells were suspended in $30 \%$ bovine albumin, and in the presence of saline as a diluent no agglutination occurred. As autoagglutination took place in venous blood withdrawn into a syringe, the above investigations were performed and read at $37^{\circ} \mathrm{C}$.'

The mild otitis media was treated with penicillin. AII R blood, $200 \mathrm{ml}$., was given by syringe, followed by a drip transfusion of $140 \mathrm{ml}$. In spite of the use of a large Bateman needle, considerable pressure was required to introduce the blood, owing to an obstruction which was thought not to be due to venospasm; it was not relieved by warming the limb, nor by the intravenous injection of $0.5 \mathrm{ml}$. of nikethamide.

During the transfusion the appearance of irregularshaped red areas in the skin of the leg proximal to the transfusion site was noted. These disappeared after about four hours, leaving no trace of bruising. Intravascular agghutination of the transfused red cells was considered to be a probable explanation for this phenomenon.

The spleen was enlarged two fingerbreadths below the costal margin after the transfusion, and it remained palpable for 24 hours.

The following day the patient was still pale and jaundiced, the haemoglobin was $44 \%(6 \cdot 2$ g.\%) and the red cell count $2 \cdot 15 \mathrm{~m}$. per c.mm. The urine contained haemoglobin, and the stools were orange brown. A second transfusion of $400 \mathrm{ml}$. of blood, from which the plasma had been removed, was given without difficulty or repetition of the previously described phenomenon. Iron therapy was begun.

Four days after admission the haemoglobin had risen to $62 \%(8 \cdot 7 \mathrm{~g} . \%)$, and the reticulocytes were $8 \cdot 4 \%$. Thereafter, there was a rapid increase in the haemoglobin level, and no further haemoglobinuria.

The patient was last seen on February 19, 1951, six weeks after the onset of the disease. The haemoglobin was $98 \%$, and the Coombs test had become negative.

Case 2. Valerie G., aged 5 years 3 months, was admitted to The Hospital for Sick Children, Great Ormond Street, on January 29, 1951, under the care of Dr. W. G. Wyllie.

One month before admission there was a three-day feverish illness with coryza. Except for two transient, unexplained pyrexial episodes, the patient was then well until the occurrence of a shivering attack two days before admission. This symptom was repeated and was followed on both occasions by the passage of dark red urine. Her mother had suffered from an influenza-like illness for three days; otherwise, the family history revealod no points of importance.

On admission to hospital the child was pale and slightly jaundiced. She had coryza but no cough or fever. The tonsils were enlarged but not injected; the tonsillar glands were palpable. A systolic murmur was present at the apex of the heart. There were rales at the base of the right lung. No enlargement of the liver or spleen was detected.

The urine was a port wine colour and contained a large amount of haemoglobin, methaemoglobin and a moderate excess of urobilin.

The haemoglobin was $59 \%(8 \cdot 2 \mathrm{~g} \%)$; the red cells, $2.55 \mathrm{~m}$. per c.mm. The percentage of reticulocytes was $1 \cdot 7$; the platelets numbered 137,700 per c.mm. There were 16,000 white cells, of which $76 \%$ were neutrophils and $21 \%$ lymphocytes. The direct Coombs, Mourant and Race test was positive on the first and seventh day after admission. The red cell fragility began at $0.48 \%$ saline concentration and was complete at $0.33 \%$. No lesion was detected in the chest radiograph. Dr. I. A. B. Cathie reported on the patient's serum:

' Group OIV R. The serum contained an antibody which caused agglutination of the red cells of 19 donors of similar group. The reaction occurred when the donor cells were suspended in both $30 \%$ bovine albumin and saline. With all the bloods in both diluents agglutination was strong at $37^{\circ} \mathrm{C}$., weak at room temperature and negative at $4^{\circ} \mathrm{C}$. The patient's serum also caused similar agglutination of her own washed and resuspended cells. The titre of the antibody was not ascertained.'

Treatment included a transfusion of $300 \mathrm{ml}$. Group OIV R blood, from which the plasma had been removed, iron, and a course of penicillin.

The haemoglobin value rose to $82 \%$, the red cell count to $3.5 \mathrm{~m}$. per c.mm., and the reticulocytes were $1.4 \%$ two days following the transfusion. There was no further haemoglobinuria. The patient made an uneventful recovery. She was discharged on February 8 , and three weeks later the haemoglobin was $91 \%$ $(12 \cdot 7 \mathrm{~g} . \%)$, the reticulocytes $2 \cdot 4 \%$ and the white cell count 10,000 per c.mm. The Coombs test was positive on this date but negative on March 19, when the patient was last reviewed and found to be healthy.

Case 3. Shirley B., aged 9 years, was admitted to St. Charles' Hospital, London, on February 14, 1950, under the care of Dr. W. G. Wyllie.

For four days before admission there was a poor appetite, the child was pale and listless, the urine was dark, and she had vomited several times each day. No relevant points were disclosed in the previous health and family history.

On admission the temperature was $101.4^{\circ} \mathrm{F}$., the pulse 128 , and the respirations 24 . The patient was a very pale, quiet girl who looked extremely ill. She was not jaundiced. The tonsils were enlarged but not injected; a few cervical glands were palpable. The 
heart sounds were accentuated, but no murmur was audible. The lungs were normal. The liver and spleen were not enlarged.

A blood count showed: Hb. $18 \%$; red cells, $1 \cdot 1 \mathrm{~m}$. per c.mm.; leucocytes, 25,000 (neutrophils 62\%, myelocytes $3 \%$, promyelocytes $1 \%$, lymphocytes $26 \%$, monocytes $1 \cdot 5 \%$ ). Nucleated red cells numbered $6 \cdot 5$ per 100 white cells; platelets, 250,000 .

A red cell fragility test showed haemolysis of $20 \%$ of cells at a saline concentration of $0.7 \%$, and $90 \%$ at $0.4 \%$ saline. As the cells tended to agglutinate spontaneously in saline, little significance could be attached to this result. The test was repeated three weeks later and the result was within normal limits.

Radiographic examination of the chest was normal.

Three days after a transfusion of three pints of blood, a blood count showed: Hb. 82\%; leucocytes, 11,000 . Slight anisocytosis and polychromasia were reported. The direct and indirect Coombs tests were negative. Total serum proteins were $6 \cdot 2 \%$ (serum albumin, $4 \cdot 7 \%$ and globulin, 1.5\%). The serum bilirubin was $1 \cdot 5$. mg. $\%$.

A bone marrow biopsy on February 22, revealed a normoblastic hyperplasia. The picture was characteristic of a post-haemorrhagic or acute haemolytic anaemia followed by a brisk marrow response. There was no evidence of leukaemia (Dr. H. I. Winner).

No cold agglutinins were detected in the serum.

Following the initial transfusion there was no further acute haemolysis, and the temperature became normal five days after admission. When last reviewed, two months after the onset of the illness, the patient was well.

Case 4. Linda P., aged 1 year 10 months, was admitted to The Hospital for Sick Children, Great Ormond Street, on March 5, 1946, under the care of Dr. Donald Paterson.

The patient was well until two days before admission. She then developed abdominal pain associated with constipation, vomited once, and passed dark urine.

On examination she was a pale, slightly jaundiced, drowsy child. Her temperature was $100^{\circ} \mathrm{F}$., pulse 140 and respirations 50 . No abnormality was elicited in the heart or lungs. The liver and spleen were both just palpable.

A blood count performed on admission showed: Hb. 20\%; red cells, 1,410,000; leucocytes, 24,000 (neutrophils $34 \%$, stabs $26 \%$, lymphocytes $34 \%$, monocytes $2 \%$ ); reticulocytes, less than $1 \%$. Red cell fragility began at $0.48 \%$ saline concentration, and was complete at $0.3 \%$. There was no auto-agghutination in the cold or at $37^{\circ} \mathrm{C}$. The blood culture was sterile. The serum Wassermann reaction and Kahn test were negative. Serum bilirubin was $2.3 \mathrm{mg} \%$; the direct Van den Bergh reaction was negative.

Sternal marrow biopsy revealed a marked normoblastic and pro-erythroblastic reaction (Dr. I. A. B. Cathie).

Radiographic examination of the chest was normal.

On April 4, Dr. R. R. Race reported on the patient's blood: - The cells are autosensitized to rabbit antihuman-serum serum. The group is OIV $\mathbf{R}$ '.
The mother's blood was $R h$. positive, and no atypical antibodies were present in her serum.

Two blood transfusions resulted in only temporary improvement, and three weeks after admission splenectomy was performed by Mr. Charles Donald. No spleniculi were seen.

Two days after the operation there was a sudden collapse with marked anaemia and jaundice. Repeated transfusions were given, but the haemolytic process persisted. The patient died on April 28, one month after splenectomy.

My thanks are due to Dr. Martin Bodian for his report on the surgical pathology and post-mortem findings:

- The spleen weighed $112 \mathrm{~g}$. with considerable congestion of pulp and reduction of lymphoid tissue. There was no erythropoiesis or evidence of reticulosis. A liver biopsy showed a normal appearance apart from moderate extramedullary erythropoiesis in portal areas. Post-mortem the body weighed $25 \mathrm{lb}$. Pallor of integument and mucous membranes was observed, aks slight jaundice, and cerebral and pulmonary oedema. The liver was enlarged ( $860 \mathrm{~g}$., normal, $380 \mathrm{~g}$ ). There were considerable numbers of iron-containing macrophages in the sinusoids, and erythropoiesis in portal areas and in the sinusoids. The bile ducts were patent. Bile in the gall-bladder contained pigments and granules. No spleniculi were found. The right femur contained red bone marrow in the proximal half, but the distal half was spindle-shaped, containing gelatinous pale marrow, and there was subperiosteal new bone formation. The bone marrow was hypocellular, showing a considerable preponderance of normoblastic cells. Other viscera gave no apposite information. Our conclusion was haemolytic anaemia of unknown aetiology.

Case 5. Paul B., aged 3 years 6 months, was admitted to the Watford and District Peace Memorial Hospital on June 11, 1947, under the care of Dr. A. White Franklin.

The patient was well until 10 days before admission, when he developed a sore throat and loss of appetite. Two days before admission he was jaundiced, and he vomited frequently. One day later his urine was noticed to be dark red. His past health and family history revealed nothing relevant.

On examination he was an apathetic, pale and jaundiced child. No abnormality was detected in the heart and lungs. The liver was just palpable; there was no enlargement of the spleen.

A blood count showed: Hb. 48\%; red cells, 3,240,000; reticulocytes, $2 \%$; leucocytes, 12,000 (neutrophils $64 \%$; lymphocytes $26 \%$ ).

In the red cell fragility test haemolysis began at $0.4 \%$ saline concentration and was complete at $0 \cdot 28 \%$. The blood urea was $53 \mathrm{mg} \%$. Urine contained $4 \mathrm{~g} . \%$ albumin; the deposit showed occasional pus cells, epithelial cells, epithelial and granular casts; strong bands of methaemoglobin were seen on spectroscopic examination. 
No growth of streptococci or diphtheroids was obtained from a throat swab.

On radiographic examination the long bones appeared normal.

In two days the haemoglobin value fell to $26 \%$. The reticulocytes were then $4 \%$, the platelets 500,000 , leucocytes 39,500, and a blood smear showed anisocytosis, poikilocytosis and polychromasia. The Coombs test was negative.

In spite of daily blood transfusions haemolysis continued. The haemoglobin value remained low until the fifth day when it rose to $56 \%$, when the reticulocytes were $45 \%$. Thereafter, the urine was free from haemoglobin, and no further transfusion was required.

The serum Wassermann reaction and Kahn test performed on June 18 were positive. The tests were repeated one week later and were then negative. The sera of the parents gave negative results.

A pyrexia of 100 to $101^{\circ} \mathrm{F}$. resolved after two weeks. The patient was discharged on July 1 when the haemoglobin had risen to $88 \%$. He was well, and there had been no recurrence of the illness when seen two months later and again in May, 1951.

\section{Revien of the Literature and Discussion}

In a comprehensive article on acute acquired haemolytic anaemia Dameshek and Schwartz (1940) referred to 100 cases of the idiopathic type reported by 80 different observers from 1907 to 1940 .

Atkinson (1940) reviewed the literature up to 1938 and discovered 59 cases of 'Lederer's anaemia ', 30 of which occurred in children.

Since 1940, 107 cases have been published, 68 of the patients being adults, and 32 children, 14 below the age of 1 year. In seven, the age was not given. The youngest patient affected was 6 weeks of age (Schoo, 1944); the oldest was a man of 77 years (Altschule and Gilligan, 1941).

It is evident that the disease may be met with at any age, but that the maximum incidence is during the first decade. Fifty per cent. of the adult cases recorded in the literature occurred in the third and fifth decades.

Sex Incidence. There was a slight preponderance of males in the proportion of 56 to 42 . In nine the sex was not stated. Of the 32 children, however, 23 were males and nine females; a similar preponderance of the male sex in this age group was also noted by Atkinson (1940).

Seasonal Incidence. A possible allergic aetiology has been cited by some observers, one of whom (Battistoni, 1946) employed intradermal peptone injections in the treatment of a case. Hay fever as a concomitant symptom was reported by Mason (1942) in a girl of 15 years. In a review of 60 cases in which the date of onset of the disease was published, there was no significant variation in incidence during any season of the year.
Heemoglobinuria. Of 101 cases in which urine examination was mentioned, haemoglobinuria was present in 25, and 12 of these were children. One report (Stats, 1943) drew attention to the favourable prognosis in cases exhibiting haemoglobinuria Indeed, 22 of the above 25 cases recovered, and seven of these made a spontaneous recovery without intravenous blood transfusion or splenectomy.

The common occurrence of the symptom in children was alluded to by Atkinson (1940) and by Dameshek and Schwartz (1940). It was present in three of the cases reported here, all of which recovered.

Hepatosplenomegaly. Splenic enlargement is by no means a constant feature of the disease. It was absent in Cases 2, 3 and 5, slight in Case 4, and only temporarily present following a transfusion in Case 1. Of 81 cases in the literature in which the condition of the spleen was described, enlargement was present in 52. In 30 cases there was enlargement of the liver.

Auto-aggatination. This has been defined as the agglutination of a patient's red cells by his own serum, due to the presence of an agglutinin in the serum and a corresponding agglutinogen in the cells.

Despite the fact that Widal (1907) claimed this phenomenon to be constant and of diagnostic value in 'acquired haemolytic icterus', it escaped notice in the literature from 1914 until Davidson's paper in 1932. In 1936 Paterson and Smith published a case in which auto-agglutination occurred; it was also mentioned in the child described by Giordano and Blum (1937), and in one of the cases published by Greenwald (1938).

Renner (1947) found 115 cases of acute haemolytic anaemia of unknown aetiology on record in the literature, and the presence of auto-agglutinins was reported in 18, or $16 \%$. He also listed 10 cases of acquired haemolytic anaemia associated with auto-agglutinins active at body temperature. The occurrence of the phenomenon at this temperature must be regarded as pathological. As Renner remarked, it was difficult to escape the conclusion that the agglutinins were responsible for red cell destruction in vivo, particularly as auto-agglutination had been found hitherto in connexion with haemolytic anaemias only (Lubinski, 1946). Kuhns and Wagley (1949) supported this hypothesis, and suggested that the auto-agglutination in their case contributed to intravascular thrombosis, and that both factors may have produced erythrostasis and further increase in blood destruction.

The association of auto-agglutination at $37^{\circ} \mathrm{C}$, haemolytic anaemia, and multiple thromboses in 
superficial leg veins and splenic vessels was noted by Young and Lawrence (1946) and by Renner (1947).

Of the five cases reported here, auto-agglutination at $37^{\circ} \mathrm{C}$ was present in Cases 1 and 2, it was absent in Cases 3 and 4, and was not tested for in Case 5. In Case 1 it was associated with a phenomenon suggestive of intravascular agglutination.

During the past ten years tests have been performed for auto-agglutinins in $\mathbf{3 8}$ recorded cases of acute haemolytic anaemia of idiopathic type. These were positive in $\mathbf{2 8}$, and in 10 the agglutinins were active at body temperature (Wiener, Reisner and Kalkstein, 1942; Evans, 1943; Lubinski, 1946; Renner and McShane, 1947; Ellis, Wollenman and Stetson, 1948; Tischendorf, Frank and Punin, 1948; Dacie, 1949; Kuhns and Wagley, 1949; Carter, Armstrong and Sydenstricker, 1949).

The significance of auto-agglutination as a primary aetiological factor in haemolytic anaemia has been disputed by Wiener (1942), who stated that it was a symptom and a result of the disease rather than the cause. A similar view was also held by Lubinski (1946), who considered that it was a test-tube reaction only, that it might be compared with the Weil-Felix reaction and the Paul-Bunnell test, and that its main importance lay in the fact that it was a source of error in blood grouping.

Haemolysins. These were first described by Chauffard and Troisier in 1908 and their occurrence in cases published in the literature was reviewed by Dameshek and Schwartz in 1940 . The isohaemolysins found in the sera of two of their own cases were thought to bear some aetiological relationship to the haemolytic state; tests for autohaemolysins were not performed.

As the result of studies in the differentiation of acquired and congenital haemolytic anaemia, Neber and Dameshek (1947) affirmed that the acquired type was due to the action of a circulating autohaemolysin on the patient's red cells. It was present in the cases described by Currie (1944), Ellis et al. (1948), Dacie (1949) and possibly also by Reisner and Kalkstein (1942). In four of these auto-agglutinins were also found.

Since 1940, of 26 cases tested, isohaemolysins were detected in only two (Haydon, 1941; Dacie, 1949).

The Coombs, Mourant and Race Test. It was first observed by Boorman, Dodd and Loutit (1946) that the red cells of patients with acquired haemolytic anaemia give a positive direct Coombs test, and that this test could be used to differentiate the acquired from the congenital type of haemolytic anaemia. They described five cases in which the test was positive: (1) a Marchiafava-Micheli syndrome, (2) and (3) refractory anaemia with signs indicative of complicating haemolysis, (4) haemolytic anaemia secondary to malignant haemangiomata of liver and spleen and (5) chronic acquired haemolytic anaemia. This finding has since been confirmed by Evans and Duane (1949), who described a positive test in nine cases of acquired haemolytic anaemia, by Neber and Dameshek (1947) in one case, and by Kidd (1949) in six cases. There are in the literature an additional 14 references to cases of the acute idiopathic type of acquired haemolytic anaemia in which the Coombs test was positive (Denys and Van den Broucke, 1947, one case; Dacie, 1949, one case; Singer and Motulsky, 1949, seven cases; Selwyn and Hackett, 1949, two cases; Herweg, 1949, 2 cases; Piney, 1950, one case). The test was performed on the five cases reported here. In three it was positive (Nos. 1, 2 and 4) and a positive result persisted after resolution of the haemolytic process up to six weeks in Case 1 and seven weeks in Case 2, at which time the test had become negative. In Cases 3 and 5, however, a negative result was obtained. Such a finding must therefore not be taken to discountenance a diagnosis of acquired haemolytic anaemia. The latter view is corroborated by the work of Wright, Dodd, Bouroncle, Doan and Zollinger (1951). These authors reported that in 10 out of 58 cases of acquired haemolytic anaemia the Coombs test was negative, and a positive result was obtained in eight out of 25 cases of the congenital type. Singer et al. (1949) made a similar observation and stated that the value of the test in the differentiation of acquired and congenital haemolytic anaemia was thus diminished.

Wasserman Reaction. A positive Wassermann reaction in association with auto-agglutination in acute acquired haemolytic anaemia has been reported by various authors, one of whom, Lubinski (1946), suggested that there might be a common antigen for both these phenomena. The antigen for the Wassermann reaction consisted of lipid and protein, and, the author stated, that for the autoagglutinins might be composed of a substance derived from protozoa, virus or toxic agents, and of some part of the red cells, one delivering the lipid and the other the protein. Both Wassermann reaction and Kahn tests were temporarily positive in Case 5 reported here.

Prognosis and Treatment. The treatment and outcome of cases culled from the literature since 1940 are illustrated in Table 1, and compared with the findings of other authors. 
TARE 1

Comparison of Recovery Rate with Method of Treatment

\begin{tabular}{|c|c|c|c|c|c|c|c|c|}
\hline & \multicolumn{2}{|c|}{ All Cases } & \multicolumn{2}{|c|}{ Group 1 * } & \multicolumn{2}{|c|}{ Group 2+ } & \multicolumn{2}{|c|}{ Group 3t } \\
\hline & Cases & Recovered & Cases & Recovered & Cases & Recovered & Cases & Recovered \\
\hline$\overline{\text { Cases published (1940-1950) }}$ & $\begin{array}{c}94 \\
\text { total } \\
32 \\
\text { children } \\
62 \\
\text { adults }\end{array}$ & $\begin{array}{c}72 \\
(77 \%) \\
29 \\
(91 \%) \\
43 \\
(69 \%)\end{array}$ & $\begin{array}{r}13 \\
7 \\
6\end{array}$ & $\begin{array}{c}12 \\
(92 \%) \\
5\end{array}$ & $\begin{array}{l}41 \\
21 \\
20\end{array}$ & $\begin{array}{c}32 \\
(78 \%) \\
18 \% \\
(85 \%) \\
14 \% \\
(70 \%)\end{array}$ & $\begin{array}{r}40 \\
4 \\
36\end{array}$ & $\begin{array}{c}28 \\
(70 \%) \\
4 \\
24 \\
(67 \%)\end{array}$ \\
\hline $\begin{array}{c}\text { Dameshek and Schwartz } \\
(1907-1940)\end{array}$ & 106 & 83 & 24 & $13 \%$ & 49 & $\begin{array}{l}45 \\
(92 \%)\end{array}$ & 33 & $-\frac{25}{(76 \%)}$ \\
\hline Carter et al. (1949) & 67 & $\begin{array}{c}53 \\
(79 \%)\end{array}$ & 3 & 2 & 24 & $(100 \%)$ & 40 & $27 \%$ \\
\hline
\end{tabular}

* Group 1. No treatment, or one or more of the following: subcutaneous, intramuscular, or intraperitoneal blood, liver extract, iron, vegetarian diet.

+ Group 2. Blood transfusion only.

: Group 3. Blood transfusion and splenectomy.

Of a total of 94 cases of all ages, $77 \%$ recovered. Only three fatal cases were recorded in children, indicating a $91 \%$ recovery rate. Atkinson, in 1940, quoted a similar figure. A less favourable prognosis, however, must be tendered in adults, in whom the recovery rate was $69 \%$. Dameshek and Schwartz (1940), in reviewing the literature up to 1940 , found 106 cases and of these, $78 \%$ recovered. Approximately the same percentage was derived from a review of 67 cases collected by Carter et al. (1949).

In discussing treatment of the disease, the cases have been divided into three groups:

Group 1. Spontaneous recovery occurred in some (Roelsen and Ohlsen, 1945; Molinari Tosatti, 1945), and in others, recovery followed treatment with a vegetarian diet (Malten, 1940), liver extract (Hanssen, 1943; Canali, 1942), iron and liver extract (Smeenk, 1940), penicillin injections (Stefanutti, 1947), subcutaneous injections of blood (Schoo, 1944, two cases), intramuscular blood (Meier, 1943, two cases), intramuscular, intraperitoneal heparinized blood and vitamin $K$ (Sterner, 1941). In all these 12 cases neither intravenous transfusion nor splenectomy was performed.

Group 2. The greater proportion of cases however required either one or more transfusions. Whole blood was usually employed, but Beard (1944) emphasized the value of plasma. An antihaemolytic factor in normal human plasma was demonstrated by Josephs (1938), and two recoveries were reported by Gasser (1945) after plasma transfusions.

It was considered by most authors, however, that the disease was self-limiting, and that haemolysis was not directly influenced by blood transfusion. Many spontaneous cures were recorded (Currie,
1944; Parsons and Hawksley, 1933), and these probably coincided with the resolution of a primary unidentified lesion or metabolic disturbance (Loutit and Mollison, 1946).

Transfusion merely maintains a safe haemoglobin level while haemolysis continues. The duration of haemolysis varied from approximately four days in Cases 1,2 and 3, to nine days in Case 5, and the number of transfusions necessary to correct the anaemia varied accordingly. Replacement transfusion employing $\mathbf{3 0}$ pints of blood was used in one case (Piney, 1950) with temporary good effect.

GrouP 3. With continuing haemolysis, splenectomy may cause a remission in some cases. Dameshek and Schwartz (1940) believe that the operation should be performed if three, or at most four, transfusions have not proved effective in controlling the disease. They stated that $100 \%$ mortality resulted from so-called expectant treatment. Dacie (1948) and Evans and Duane (1949), also advocated splenectomy, affirming that it offered the only hope of a real remission in the majority of patients.

The efficacy of this line of therapy was variable, and a group of cases occurred in which neither transfusion nor splenectomy was of any value in terminating haemolysis. Of 40 cases in which splenectomy was performed, 12 died. A similar mortality rate was reported by Carter et al. (1949), $50 \%$ of the deaths resulting from post-operative complications. In the cases recorded by Dameshek (1943), $50 \%$ of the fatalities were due to continuing haemolysis, and this was also responsible in Case 4 reported here, the patient dying one month following splenectomy despite repeated transfusions. Discouraging results have been reported by Thompson (1936), Dyke and Young (1938) and Haydon (1941).

From Table 1 it is evident that in 90 patients 
receiving intravenous transfusion alone the survival rate was $86 \%$; while of 73 who underwent splenectomy $72 \%$ recovered. It may be concluded that operative treatment is of value for those patients in whom continued transfusion is no longer practicable.

Many cases have been published in which recovery followed repeated transfusions and in which splenectomy was not performed (Kettner, 1947; Ellis et al., 1948; Buch, 1948; Selwyn and Hackett, 1949; Herweg, 1949). In one (Loutit and Mollison, 1946) the patient declined operation and subsequently recovered.

Encouraging reports have recently appeared regarding the use of A.C.T.H. in the treatment of acquired haemolytic anaemia. Improvement followed in five cases (Gardner, 1950; Dameshek, 1950), and recovery in one case (Davidson, Duthie, Girdwood and Sinclair, 1951), a dose of $100 \mathrm{mg}$. daily for 10 days being employed in the latter. Little or no response resulted from this therapy in two cases of congenital haemolytic anaemia.

Aetiology. Although auto-agglutinins or autohaemolysins may explain the mechanism of the anaemia in some cases, the primary cause or stimulus to the production of these antibodies remains an enigma. One theory advanced by Lubinski (1946) was that the antigen for autoagglutinins might be composed of a substance derived from protozoa, toxic agents or viruses, and of some part of the red cells. Another (Mendell, Meranze and Meranze, 1936) proposed that a circulating toxin was perhaps the aetiological factor suggested by the presence of degenerative granules within a large number of the granulocytes.

Erythrophagocytosis by monocytes in the peripheral blood was reported by Landolt (1946) and by Hargraves, Herrell and Pearman (1941).

In Cases 1 and 2 the patients had been in contact with respiratory infections of probable virus origin, and both had symptoms of upper respiratory tract infection. Chest radiographs revealed no abnormality, but virus infection was a possible aetiological factor in these two instances.

\section{Summary}

The diagnostic criteria of acute idiopathic haemolytic anaemia are defined.

Five cases of the disease occurring in children are reported, two of which showed auto-agglutination at body temperature.

One hundred and seven case reports published since 1940 are analysed, and the literature reviewed, with particular reference to cases in children.
The significance of auto-agglutination at $37^{\circ} \mathrm{C}$ is discussed, and references to 10 cases of this disease showing the phenomenon are given.

A negative Coombs test in two cases is reported, and the value of the test in differentiating the congenital and acquired types of haemolytic anaemia is discussed.

A recovery rate of $90 \%$ is to te expected in children, and $70^{\circ}$ in adults.

Spontaneous recovery may occur but most patients require transfusion. A proportion of those exhibiting continuing haemolysis in whom transfusion is no longer practicable may show a remission following splenectomy.

The aetiology of the disease is briefly discussed.

I wish to thank Dr. W. G. Wyllie for his encouragement, advice and permission to publish Cases 1,2 and 3 . My thanks are also due to Dr. I. A. B. Cathie for his helpful criticism, and to Dr. Donald Paterson and Dr. A. White Franklin for allowing me to publish Cases 4 and 5 respectively.

\section{REFERENCES}

Altschule, M. D. and Gilligan, D. R. (1941). Arch. intern. Med., 68, 957.

Atkinson, F. R. B. (1940). Brit. J. Child. Dis., 37, 35.

Battistoni, L. (1946). Clin. nuova, 2, 176.

Beard, M. F. (1944). Sth. med. J. (Bgham., Ala.), 37, 448.

Boorman, K. E., Dodd, B. E. and Loutit, J. F. (1946). Lancet, 1, 812.

Buch, H. (1948). Acta. med. scand. (supp. 213), 99.

Canali, G. (1942). Haematologica, 24, 469.

Carter, C. H., Armstrong, E. S. and Sydenstricker. V. P. (1949). J. med. Ass. Ga., 38, 52.

Chauffard, M. A., Troisier, J. and Vincent, C. (1908). Sem. med., B. Aires, 28, 345.

Currie, J. P. (1944). Brit. med. J., 2, 8.

Dacie, J. V. (1949). Blood, 4, 928.

Dameshek, W. (1950). Blood, 5, 791.

- (1943). Clinics, 2, 118.

__ and Schwartz, S. O. (1940). Medicine, 19, 231.

Davidson, L. S. P. (1932). Quart. J. Med., 25, (n.s. 1). 543.

Duthie, J. J. R., Girdwood, R. H. and Sinclair, R. J. G. (1951). Brit. med. J., 1, 657.

Denys, P. and Van den Broucke, J.' (1947). Arch. franç. Pédiat., 4, 205.

Dyke, S. C. and Young, F. (1938). Lancet, 2, 817.

Ellis, L. B., Wollenman, O. J. and Stetson, R. P. (1948). Blood, 3, 419.

Evans, R. S. (1943). Stanford med. Bull., 1, 178.

and Duane, R. (1949). Calif. Med., 70, 244.

Gardner, F. (1950). Blood, 5, 791.

Gasser, C. (1945). Helv. paediat. Acta., 1, 38.

Giordano, A. S. and Blum, L. L. (1937). Amer. med. Sci., 194, 311.

Greenwald, H. M. (1938). Ibid., 196, 179.

Haydon, R. L. (1941). Surg. Clin. N. Amer., 21, 1453.

Hanssen, P. (1943). Acta. med. scand., 113, 251.

Hargraves, M. M., Herrell, W. E. and Pearman, R. O. (1941). Proc. Mayo Clin., 16, 107.

Herweg, J. (1949). J. Pediat., 35, 637.

Josephs, H. W. (1938). Bull. Johns Hopk. Hosp., 62, 53. 
Kettner, M. (1947). Z. Kinderheilk., 65, 1.

Kidd, P. (1949). J. clin. Path., 2, 103.

Kuhns, W. J. and Wagley, P. F. (1949). Ann. intern. Med., 30, 408.

Landolt, R. F. (1946). Helv. paediat. Acta., 1, 335.

Loderer, M. (1925). Amer. J. med. Sci., 170, 500.

- (1930). Ibid., 179, 228.

Loutit, J. F. and Mollison, P. L. (1946). J. Path. Bact., 58, 711 .

Lubinski, H. and Goldbloom, A. (1946). Amer. J. Dis. Child., 72, 325.

Malten, H. (1940). Münch. med. Wschr., 87, 1207.

Mason, V. R. (1942). Trans. Ass. Amer. Phys., 57, 234.

Meier, K. (1943). Ann. paediat. (Basel), 161, 244.

Mendell, T. H., Meranze, D. R. and Meranze, T (1936). Amer. J. med. Sci., 192, 316.

Molinari, P. Tosatti (1945). Haematologica, 27, 337.

Neber, J. and Dameshek, W. (1947). Bull. New Engl. med. Cent., 9, 166.

Parsons, L. G. and Hawksley, J. C. (1933). Archives of Disease in Childhood, 8, 184.

Patterson, W. H. and Smith, G. S. (1936). Lancet, 2 , 1096

Piney, A. (1950). Sang., 21, 229.

Reisner, E. H. and Kalkstein, M. (1942). Amer. J. med. Sci., 203, 313.

Renner, W. F. and McShane, J. R. (1947). Sth. med. J. (Bgham. Ala.), 40, 973.

Roelsen, E. and Ohlsen, A. Soeborg (1945). Acta med. scand., $122,60$.

Schoo, A. (1944). Ann. paediat. (Basel), 163, 51.

Selwyn, J. G. and Hackett, W. E. R. (1949). J. clin. Path., 2, 114.

Singer, K. and Motulsky, A. G. (1949). J. Lab. clin. Med., 34, 768

Smeenk, C. (1940). Ned. Tijdschr. Geneesk., 84, 1822.

Stats (1949). J. Pediat., 34, 105.

Stefanutti, P. (1947). Policlinico (prat.), 54, 1157.

Sterner, L. G. (1940). Acta. paediat., 28, 196.

Thompson, W. P. (1936). J. Amer. med. Ass., 107, 1776.

Tischendorf, W., Frank, A. and Punin, W. (1948). Klin. Wschr., 26, 262.

Widal, F., Abrami, P. and Brule, M. (1907). Pr. méd., 15, 641.

Wiener, A. S. (1942). Amer. J. clin. Path., 12, 189.
Wright, C. S., Dodd, M. C., Bouroncle, B. E., Doan, C. A. and Zollinger, R. M. (1951). J. Lab. clin. Med., 37, 165.

Young, L. E. and Lawrence, J. S. (1946). Arch. intern. Med., 77, 151.

\section{BiBLlOGRAPHY}

Acuna, M. and Gambirassi, A. C. (1942). Arch. argent. Pediat., 17, 421.

Amado, P. (1948). Gaz. méd. portug., 1, 5.

Arcuri, F. and Chiti, E. (1948). Arch. "Maragliano" Patol. Clin., 3, 433.

Bindschedler, Apffel and Adrian (1946). Arch. franç. Pédiat., 3, 89.

Castellanos, A. and Montero, R. (1940). Arch. Soc. Estud. clin. Habana, 34, 387. (1940). Arch. Med. interna., 6, 232.

Cheney, G. and Denenholz, E. J. (1945). Med. Clin. N. Amer., 29, 695.

D'Alessandro, G. (1940). Policlinico (prat.), 47, 1035.

David, J. K. and Minot, A. S. (1944). Amer. J. Dis. Child., 68, 327.

Fisher, J. A. (1947). Quart. J. Med., 16, 245.

Fontan, Verger, P. and Féraut (1947). Arch. franc. Pédiat., 4, 33.

Germini, P. (1946). Policlinico (prat.), 53, 527

Hoyer, K. (1941). Nord. Med. (Hospitalstid), 1, 3387.

Jones, C. S. (1945). S. Afr. med. J., 19, 470.

Kjellberg, K. (1941). Kinderärztl. Praxis., 12, 296 (1942). Nord. Med., 14, 1692 (abstr. of above).

Meier, K. (1944). Ann. paediat. (Basel), 162, 140.

Metzger, H. and Lévy, J. G. (1948). Paris méd., 38, 337.

Mollison, P. L. (1947). Clin. Sci., 6, 137.

Moser, P. and Spielmann, W. (1950). Z. ges. inn. Med., 5, 417.

Novelli, E. (1947). Arch. "Maragliano" Patol. Clin., 2. 525 .

Papayannopoulos, G. (1947). Brit. med. J., 2, 371.

Pavlovsky, A. and Quirno, N. (1943). Dia. med., 15, 190.

Rao, S. V. and Rao, A. S. (1940). Antiseptic, 37, 1087.

Sabta, G. (1946). Haematologica, 29, 399.

Schrifrin, N. (1949). J. Pediat., 34, 103.

Spira, M. (1943). Z. Kinderheilk., 64, 187.

Ytrehus, O. (1947). Nord. Med., 34, 1113. 